Review

\title{
Zoo-Technical Features of Tabun Horses in Almaty Region of Republic of Kazakhstan
}

\author{
${ }^{1}$ Shynggys Assilbekov, ${ }^{1}$ Kairat Iskhan, ${ }^{2}$ Nursultan Japashov and ${ }^{1}$ Aidana Orynbassarova \\ ${ }^{1}$ Kazakh National Agrarian Research University, Almaty, Kazakhstan \\ ${ }^{2}$ Al-Farabi Kazakh National University, Almaty, Kazakhstan
}

\author{
Article history \\ Received: 01-11-2020 \\ Revised: 21-01-2021 \\ Accepted: 21-01-2021 \\ Corresponding Author: \\ Shynggys Assilbekov \\ Kazakh National Agrarian \\ Research University, Almaty, \\ Kazakhstan \\ Email: shynggys.asilbekov@gmail.com
}

\section{Introduction}

More than a thousand years ago, on the territory of modern Kazakhstan, nomadic peoples had horses similar to modern Kazakh horses of the toad type (Kargayeva et al., 2020). From ancient times, the horses served nomadic people for riding and as meat and dairy animals. Centuries-old natural selection under the influence of harsh climatic conditions with extensive management of herd horse breeding and artificial selection that meets the requirements for horses in nomadic economy were the main factors in the formation of Kazakh horses (Egorova, 2017). Their valuable advantage was their high adaptability to pasture maintenance throughout the year. The conditions of herd horse breeding have not changed much over the centuries, so Kazakh horses have been preserved without noticeable changes (Akimbekov et al., 2018; Sataev et al., 2018).

\begin{abstract}
This work was attended to improve and show the comparative characteristics of exterior features, assessment of the constitutional type mares bred in LLP "AKBOZ" of Alection of the productive profle herd horse breeding contains a high number of nitrogen-containing substances with a reduced content of intramuscular fat. Therefore, horse meat is a dietary product available to a significant part of the population Republic of Kazakhstan. Meat herd horse breeding requires amount of pasture land significantly contributes not only to an increase in the number of herd horses, but also to an increase in the production of high-value meat-horse meat. The results of individual appraisal showed hat modern Kazakh horses of the zhabe type (or toad type) are quite arge, have a high live weight. The young growth in measurements and appraisal class. It was found that the greatest increase in live weight in foals was observed from 3 days of age to 1 month and was $40.8 \mathrm{~kg}$ in stallions and $40.4 \mathrm{~kg}$ in fillies. The average daily increase was 1511 and $1496 \mathrm{~g}$, respectively. From 1 to 6 months of age, the increase in live weight is $84.8 \mathrm{~kg}$ in stallions, $83.0 \mathrm{~kg}$ in fillies, the average daily increase
\end{abstract}

Keyword: Kazakh Horse Type Toad (Zhabe), Horses' Parameters, Horses' Live Weight, Horses' Body Measurements, Horses' Growth

The role of Kazakh horses such as a toad as meat and dairy animals is exceptionally great. To improve the productive qualities of local herd horses, Kazakh toad-type horses are used along with the Kushum and Mugalzhar type of horses. Figure 1 shows Kazakh horses' type zhabe.

Since the mid-1950s, the concept of "meat horse breeding" as a developing sub-sector of horse breeding has become firmly in use. During this period, many animal scientists raise the question not only about increasing the meat productivity of horses, but also about creating specialized breeds and types (Akimbekov and Yuldashbaev, 2017).

Currently, meat and dairy horse breeding in the Republic is mainly developed due to the breeding of Kazakh horses of the zhabe type (in farms, $70 \%$ of milk is obtained from this breed). There are lines and factory types of Kazakh zhabe horses that can be used to improve local herds of kushum breed (Zhumagaliyeva et al., 2015; Akimbekov, 2013). 

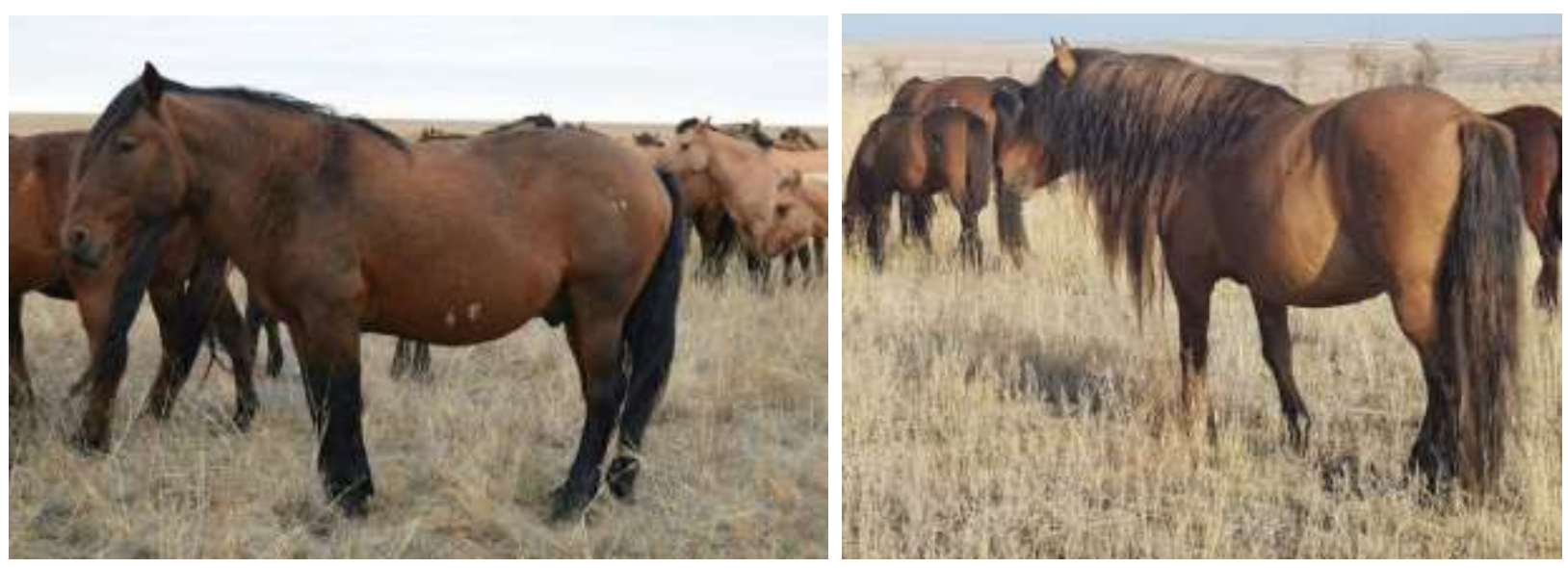

Fig. 1: Kazakh horses of the zhabe type

In the Republic of Kazakhstan, there is a steady increase in the number of horses.

In particular the number of horses has increased over 11 years from 1,235600 in 2007 to 2,300,000 in 2018 The increase amounted to 100000644 goals or $86,1 \%$. Of all the horses $80 \%$ are bred by the herd method and are focused on the production of horse breeding products-breeding stock, horse's meat and horse's milk "kumys". Kumys is an acidic drink made from mare's milk the main trends in the development of productive horse breeding are the growth of the animal population mainly due to domestic breeds of horses of meat and dairy productivity such as kushum type of horse, Mugalzhar and Kazakh horses of the zhabe type. Stallions of these breeds are used as improvers of local populations of herd horses and mares - for thoroughbred breeding. In the future, the number of horses in all regions of Kazakhstan will continue to grow dynamically (Ombaev, 2013).

Increasing the genetic potential of productivity of local Kazakh horses is mainly carried out through the use of proven methods and techniques of breeding, breeding new plant types and lines with high meat and dairy productivity.

Kazakhstan's horse breeding needs to focus on the genetic resources of created high-value genotypes of horse breeds adapted to the specific natural and climatic zone of the South-East of Kazakhstan.

In the conditions of the Almaty region, the kushum type of horse is of particular interest-a massive type, which is the most acceptable for the selection process with the local population of Kazakh horses of the zhabe type. This will allow us to produce high-quality products such as milk and horse meat.

This paper's aim is to provide comparitative characteristics of kazakh Horses type zhabe in Almaty region of Republic of Kazakhstan. Comparative characteristics of exterior features, assessment of the constitutional type of horses, determination of the direction of the productive profile of female horses.

\section{Methodology}

The research was carried out in the stud farm in Almaty region, engaged in breeding Kazakh horses of the zhabe type and the mugalzhars breed.

Bonitation (assessment) was carried out in accordance with the order of the Minister of Agriculture of the Republic of Kazakhstan dated 27.05.16, No. 239 "Instructions for bonitation (assessment) of the breeding value and reproduction of local and farm horses."

The growth rate of stallions and mares was studied on the basis of determining the live weight, by individual weighing at the age of 3 days, 1.3 and 6 months. The live weight of mares and features of the body type are estimated by the results of grading for age groups (3.5, 5.5, 7.5 years). We measured the main body measurements and calculated body indices based on them.

It was studied 763 horses. The main characteristics for the evaluation of horses were as follows:

- The height in the hoop - measured with a measuring stick from the ground to the highest point of the hoop vertically. Promer took a measuring stick from the ground to the highest point of the hoop vertically with an accuracy of $1 \mathrm{~cm}$

- Oblique length of the torso - measured with a measuring stick or tape from the anterior protrusion of the shoulder joint to the posterior point of the saddle. Promer took a measuring stick from the anterior protrusion of the shoulder-shoulder joint to the posterior point of the saddle bug

- Circumference of the breast - measured with a measuring tape along the vertical circumferential angle of the shoulder blades. Promer took a measuring tape along the vertical to the back corner of the shovel 
- Circumference of the pelvis - measured with a measuring tape in the lower part of the upper third of the pelvis (in the narrowest place). Horse girth was measured with a measuring tape with an accuracy of $0.5 \mathrm{~cm}$

- $\quad$ Living mass was measured on special scales

\section{Results}

In the selection and breeding work mass selection has been applied since 2015. Mass selection is carried out according to the following criteria: Measurements of the body, constitutional body type, body weight, adaptive quality. Since 2019, along with mass selection, individual selection has already been carried out. The selection of horses was based on a set of characteristics, ranking horses with low live weight and unsatisfactory adaptability to the herd content. In 2019 carried out the appraisal (bonitation) of horses (Table 1).

It was found that out of 763 heads of rated horses, 309 heads $(40.5 \%)$ were assigned to the elite class, 324 heads $(42.5 \%)$ to the I class and 130 heads $(17.0 \%)$ to the II class. Stallions-producers 22 heads all class elite. All rated livestock of horses are measured and weighed (Table 2).
The results of individual bonitation showed that Kazakh horses of the toad type are quite large and have a high live weight. Young animals in size and live weight exceed the corresponding requirements for animals of the I bonitation class. Stallions-producers of the Kazakh horse type zhabe on average have a live weight of $461.4 \pm 2.6 \mathrm{~kg}$, a height at the withers of $145.2 \pm 0.49 \mathrm{~cm}$, an oblique length of the trunk of $151.05 \pm 0.64 \mathrm{~cm}$, a chest girth of $184.3 \pm 0.75 \mathrm{~cm}$ and a pastern girth of $19.5 \pm 0.19 \mathrm{~cm}$. On average, horses showed a live weight of $432.1 \pm 3.8$, a height at the withers of $143.1 \pm 0.39 \mathrm{~cm}$, an oblique body length of $149.3 \pm 0.48 \mathrm{~cm}$, a chest girth of $180.2 \pm 0.42 \mathrm{~cm}$ and a pastern girth of $18.5 \pm 0.17 \mathrm{~cm}$.

Stallions at 1.5 years of age have a live weight of $325.8 \pm 3.8 \mathrm{~kg}, 2.5$ years-405.4 $\pm 3.1 \mathrm{~kg}$ and 3.5 years$442.5 \pm 2.9 \mathrm{~kg}$. Fillies showed live weight at 1.5 years of age $309.8 \pm 3.9 \mathrm{~kg}$ and 2.5 years of age $368.7 \pm 3.6 \mathrm{~kg}$.

In 2019, 162 heads of foals were received improved by stallions-producers of the kushum breed ( 40 heads per 100 stallions). The study of the growth and development of foals was carried out. The main criteria were age and seasonal changes in live weight and body measurements of young animals (Table 3 ).

Table 1: Class composition of Kazakh horses of the zhabe type in study farm

\begin{tabular}{|c|c|c|c|c|c|c|c|}
\hline \multirow[b]{3}{*}{ Age and gender group } & \multirow[b]{3}{*}{$\mathrm{N}$} & \multicolumn{6}{|c|}{ Rating (bonitation) classes } \\
\hline & & \multirow{2}{*}{\begin{tabular}{l} 
Elite \\
\hdashline $\mathrm{n}$
\end{tabular}} & \multirow{2}{*}{$\begin{array}{c}\text { I } \\
\%\end{array}$} & \multicolumn{2}{|l|}{ II } & \multirow[b]{2}{*}{$\mathrm{n}$} & \multirow[b]{2}{*}{$\%$} \\
\hline & & & & $\mathrm{n}$ & $\%$ & & \\
\hline 1 & 2 & 3 & 4 & 5 & 6 & 7 & 7 \\
\hline Manufacturing stallions & 22 & 22 & 100 & - & - & - & - \\
\hline Mare & 405 & 153 & 37,8 & 182 & 44,9 & 70 & 17,3 \\
\hline Stallions 3.5 years & 63 & 35 & 55,6 & 19 & 30,1 & 9 & 14,3 \\
\hline Stallions 2.5 years & 35 & 12 & 34,3 & 17 & 48,6 & 6 & 17,1 \\
\hline Stallions 1.5 years & 64 & 25 & 39,1 & 26 & 40,6 & 13 & 20,3 \\
\hline Fillies 2.5 years & 65 & 24 & 36,9 & 29 & 44,6 & 12 & 18,5 \\
\hline Fillies 1.5 years & 109 & 38 & 34,9 & 51 & 46,8 & 20 & 18,3 \\
\hline Total rated & 763 & 309 & 40,5 & 324 & 42,5 & 130 & 17,0 \\
\hline
\end{tabular}

Table 2: Measurements and live weight of Kazakh horses of the zhabe type

\begin{tabular}{|c|c|c|c|c|c|c|}
\hline \multirow[b]{2}{*}{ Age and gender group } & \multirow[b]{2}{*}{$\mathrm{N}$} & \multicolumn{4}{|c|}{ Measurements, $\mathrm{cm}$} & \multirow[b]{2}{*}{$\begin{array}{l}\text { Live } \\
\text { weight, } \mathrm{kg}\end{array}$} \\
\hline & & $\begin{array}{l}\text { Height at } \\
\text { withers }\end{array}$ & $\begin{array}{l}\text { Oblique length } \\
\text { of the body }\end{array}$ & $\begin{array}{l}\text { Chest } \\
\text { circumference }\end{array}$ & Pastern girth & \\
\hline 1 & 2 & 3 & 4 & 5 & 6 & 7 \\
\hline \multirow[t]{2}{*}{ Manufacturing stallions } & 22 & $145,2 \pm 0,49$ & $151,05 \pm 0,64$ & $184,3 \pm 0,75$ & $19,5 \pm 0,19$ & $461,4 \pm 2,6$ \\
\hline & Standard & 144 & 149 & 178 & 19 & 440 \\
\hline \multirow[t]{2}{*}{ Mare } & 405 & $143,1 \pm 0,39$ & $149,3 \pm 0,48$ & $180,2 \pm 0,42$ & $18,5 \pm 0,17$ & $432,1 \pm 3,8$ \\
\hline & Standard & 142 & 148 & 177 & 18,5 & 420 \\
\hline Stallions 3.5 years & 63 & $144,5 \pm 0,43$ & $147,6 \pm 0,51$ & $181,8 \pm 0,77$ & $19,0 \pm 0,18$ & $442,5 \pm 2,9$ \\
\hline Stallions 2.5 years & 35 & $138,7 \pm 0,52$ & $139,8 \pm 0,61$ & $172,4 \pm 0,82$ & $18,5 \pm 0,19$ & $405,4 \pm 3,1$ \\
\hline Stallions 1.5 years & 64 & $132,4 \pm 0,61$ & $131,8 \pm 0,72$ & $168,8 \pm 0,88$ & $17,5 \pm 0,17$ & $325,8 \pm 3,8$ \\
\hline Fillies 2.5 years & 65 & $136,5 \pm 50,49$ & $135,1 \pm 0,58$ & $170,1 \pm 0,79$ & $18,0 \pm 0,18$ & $368,7 \pm 3,6$ \\
\hline Fillies 1.5 years & 109 & $130,6 \pm 0,58$ & $129,7 \pm 0,61$ & $165,6 \pm 0,75$ & $17,5 \pm 0,19$ & $309,8 \pm 3,9$ \\
\hline
\end{tabular}


The obtained data allow us to specialize in the meat sector in order to increase the export potential of domestic horse breeding (Baimukanov et al., 2017).

Improved foals of the Kazakh horse zhabe differ in high live weight at birth. Stallions at birth have a live weight of $48.7 \pm 1.87 \mathrm{~kg}$, fillies $47.2 \pm 1.62 \mathrm{~kg}$. When reaching the age of three months, the live weight of stallions and mares increases 1.7 times.

It was found that the greatest increase in live weight in foals born in 2018 was observed from 3 days of age to 1 month and was $40.8 \mathrm{~kg}$ in stallions and $40.4 \mathrm{~kg}$ in fillies. The average daily increase was 1511 and 1496, respectively. From 1 month to 6 months of age, the increase in live weight is $84.8 \mathrm{~kg}$ in stallions, $83.0 \mathrm{~kg}$ in fillies, the average daily increase was 543 and 532, respectively.

By the live weight of foals, it is not always possible to determine in which direction the animal's body is developing. The answer to this question is given by studying changes in exterior features during development. In the postnatal period, the higher growth energy of foals is noted in the axial and weaker in the peripheral parts of the body. If from 3 day to 6 months of age the measurements of height at withers increased the by 26.0 colts and fillies $26,2 \mathrm{~cm}$, metacarpus 4.0 and 3.7 $\mathrm{cm}$, the measurements of the oblique length of the trunk increased by 33.2 and $31.9 \mathrm{~cm}$, bust 27.9 and $25.6 \mathrm{~cm}$, respectively. Thus, the most intensive growth of all body parts in foals occurred in the first six months of life.

To fully characterize the overall development of young animals, the body indices of foals were determined (Table 4).

In summer and winter time, horses reduce their fatness, therefore, for the uninterrupted production of horse meat, in addition to the spring and autumn feeding, horse fattening is practiced regardless of age. Summer fattening was held from July 3 to September 3. Stallions were put on fattening at the age of 1 year and 2 years of age. Winter fattening was held from November 5 to January 5 for foals at the age of 6,18 , 30 months.

Fattening of horses was conducted with regard to their live weight and fatness. The conditions of keeping colts of all ages were the same.

Table 3: Age dynamics of measurements and live weight of young horses in study farm

\begin{tabular}{|c|c|c|c|c|c|c|c|}
\hline \multirow[b]{2}{*}{ Age months } & \multirow[b]{2}{*}{$\mathrm{n}$} & \multicolumn{4}{|c|}{ Measurements, $\mathrm{cm}$} & \multirow[b]{2}{*}{$\begin{array}{l}\text { Live } \\
\text { weight, } \mathrm{kg}\end{array}$} & \multirow[b]{2}{*}{$\begin{array}{l}\text { Average daily } \\
\text { growth, g }\end{array}$} \\
\hline & & $\begin{array}{l}\text { Height at } \\
\text { withers }\end{array}$ & $\begin{array}{l}\text { Oblique length } \\
\text { of the body }\end{array}$ & $\begin{array}{l}\text { Chest } \\
\text { circumference }\end{array}$ & $\begin{array}{l}\text { Pastern } \\
\text { girth }\end{array}$ & & \\
\hline 1 & 2 & 3 & 4 & 5 & 6 & 7 & 8 \\
\hline \multicolumn{8}{|l|}{ Colts } \\
\hline 3 days & 65 & $92,7 \pm 0,53$ & $80,2 \pm 0,47$ & $96,7 \pm 0,67$ & $11,7 \pm 0,17$ & $48,7 \pm 1,87$ & - \\
\hline 1 & 64 & $101,5 \pm 0,62$ & $91,7 \pm 0,59$ & $106,1 \pm 0,64$ & $13,2 \pm 0,21$ & $89,5 \pm 2,09$ & 1511 \\
\hline 3 & 62 & $113,2 \pm 0,67$ & $105,3 \pm 0,641$ & $115,8 \pm 0,60$ & $14,5 \pm 0,18$ & $130,9 \pm 2,17$ & 679 \\
\hline 6 & 60 & $118,7 \pm 0,67$ & $113,4 \pm 0,71$ & $124,6 \pm 0,74$ & $15,7 \pm 0,16$ & $174,3 \pm 2,31$ & 477 \\
\hline \multicolumn{8}{|l|}{ Fillies } \\
\hline 3 days & 76 & $91,4 \pm 0,48$ & $79,6 \pm 0,53$ & $95,8 \pm 0,57$ & $11,4 \pm 0,11$ & $47,2 \pm 1,62$ & - \\
\hline 1 & 76 & $100,2 \pm 0,51$ & $90,4 \pm 0,45$ & $104,8 \pm 0,52$ & $12,6 \pm 0,12$ & $87,6 \pm 2,01$ & 1496 \\
\hline 3 & 72 & $110,5 \pm 0,57$ & $103,7 \pm 0,51$ & $113,6 \pm 0,50$ & $14,1 \pm 0,10$ & $128,1 \pm 2,28$ & 664 \\
\hline 6 & 70 & $117,6 \pm 0,62$ & $111,5 \pm 0,58$ & $121,4 \pm 0,47$ & $15,1 \pm+0,12$ & $170,6 \pm 2,42$ & 374 \\
\hline
\end{tabular}

Table 4: Age changes in the physique indices of foals of AKBOZ LLP

\begin{tabular}{|c|c|c|c|c|c|}
\hline \multirow[b]{2}{*}{ Age, months } & \multirow[b]{2}{*}{$\mathrm{N}$} & \multicolumn{4}{|c|}{ The build indexes, $\%$} \\
\hline & & Format & Coverage & Bones & Massivenesses \\
\hline 1 & 2 & 3 & 4 & 5 & 6 \\
\hline \multicolumn{6}{|l|}{ Colts } \\
\hline 3 days & 65 & 86,5 & 104,3 & 12,6 & 60,9 \\
\hline 1 & 64 & 90,3 & 104,5 & 13,0 & 86,0 \\
\hline 3 & 62 & 92,8 & 102,1 & 12,8 & 89,6 \\
\hline 6 & 60 & 95,5 & 105,0 & 13,2 & 104,4 \\
\hline \multicolumn{6}{|l|}{ Fillies } \\
\hline 3 days & 76 & 87,1 & 104,8 & 12,5 & 62,1 \\
\hline 1 & 76 & 90,2 & 104,6 & 12,6 & 86,7 \\
\hline 3 & 72 & 93,8 & 102,8 & 12,8 & 94,9 \\
\hline 6 & 70 & 94,8 & 103,2 & 12,8 & 104,7 \\
\hline
\end{tabular}


Table 5: Composition and nutritional value of actually eaten diets during the fattening of young horses

\begin{tabular}{|c|c|c|c|c|c|}
\hline \multirow[b]{3}{*}{ Feed type } & \multicolumn{5}{|c|}{ Age, months } \\
\hline & \multicolumn{2}{|c|}{ Summer fattening } & \multicolumn{3}{|c|}{ Winter fattening } \\
\hline & 12 & 14 & 6 & 18 & 30 \\
\hline 1 & 2.00 & 3.00 & 4.00 & 5.00 & 6.00 \\
\hline Steppe hay, kg & 2.50 & 3.00 & 2.00 & 3.00 & 3.00 \\
\hline Winter rye hay, $\mathrm{kg}$ & 3.00 & 3.00 & 3.00 & 3.00 & 3.00 \\
\hline Crushed barley, $\mathrm{kg}$ & 1.50 & 2.5 & 1.00 & 2.00 & 3.00 \\
\hline \multicolumn{6}{|c|}{ The diet includes: } \\
\hline Feed units & 3.13 & 4.20 & 2.49 & 3.78 & 5.12 \\
\hline Dry matter, kg & 4.43 & 5.71 & 3.57 & 5.28 & 7.08 \\
\hline Digestible protein, $g$ & 482.00 & 674.00 & 374.00 & 591.00 & 828.00 \\
\hline Calcium, g & 21.10 & 19.10 & 12.20 & 17.80 & 22.70 \\
\hline Phosphorus, g & 10.10 & 13.50 & 7.90 & 12.40 & 15.40 \\
\hline Carotene, mg & 113.70 & 127.20 & 100.50 & 127.00 & 159.50 \\
\hline
\end{tabular}

Table 6: Live weight and live weight gain of foals during fattening (duration of experiments - 60 days)

\begin{tabular}{|c|c|c|c|c|c|}
\hline \multirow[b]{3}{*}{ Indicator } & \multicolumn{5}{|c|}{ Age, months } \\
\hline & \multicolumn{2}{|c|}{ Summer fattening } & \multicolumn{3}{|c|}{ Winter fattening } \\
\hline & 12 & 24 & 6 & 18 & 30 \\
\hline 1 & 2 & 3 & 4 & 5 & 6 \\
\hline Number of heads & 20 & 20 & 20 & 20 & 20 \\
\hline \multicolumn{6}{|l|}{ Live weight, kg: } \\
\hline At the beginning of fattening & $232.3 \pm 3.7$ & $273.6 \pm 4.1$ & $181.3 \pm 3.2$ & $263.2 \pm 3.8$ & $348.1 \pm 5.2$ \\
\hline At the end of fattening & $278.1 \pm 3.5$ & $315.2 \pm 3.9$ & $228.6 \pm 3.3$ & $303.9 \pm 3.5$ & $385.6 \pm 4.6$ \\
\hline \multicolumn{6}{|l|}{ Live weight gain: } \\
\hline Gross, kg & $45.8 \pm 2.6$ & $41.6 \pm 2.9$ & $47.3 \pm 2.4$ & $40.7 \pm 2.5$ & $37.5 \pm 3.3$ \\
\hline Daily average, $g$ & $763.3 \pm 40.8$ & $693.3 \pm 46.3$ & $788.3 \pm 42.1$ & $678.3 \pm 50.7$ & $625,0 \pm 53,6$ \\
\hline
\end{tabular}

The main diet consisted of fodder available on the farm: Steppe hay (konirbas), winter rye of milkywax ripeness and crushed phenomenon. Their quality was satisfactory. The composition and nutritional value of the rations are given in Table 5 .

The nutritional value of the actually eaten ration with summer fattening in 12-month-old-stallions was 3.13 feed units and $482 \mathrm{~g}$ of digestible protein and in 24 monthly foals -4.20 feed units and $674 \mathrm{~g}$ of digestible protein; in winter fattening in 6-month-old foals had a nutritional ration of 2.49 feed units and $374 \mathrm{~g}$ of digestible protein, in 18-month-old foals - 3.78 feed units and $591 \mathrm{~g}$ of digestible protein, in 30-month-old foals - 5.12 feed units and $828 \mathrm{~g}$ of digestible protein. Per $100 \mathrm{~kg}$ of live weight there was used $2.44 \mathrm{~kg}$ of dry matter of the ration for 12-month-old stallions, $2.09 \mathrm{~kg}$ of DM for 24-month-olds during the summer fattening, for 6-month-old foals - $1.97 \mathrm{~kg}$ of DM, for 18-monthold stallions - $2.03 \mathrm{~kg}$ of DM during the winter fattening. Per $1 \mathrm{~kg}$ of the gained live weight, 4.1 feed units were consumed for 12 monthly stallions, 6.06 feed units for 24-month-olds, 6.7 feed units for 6-month-old stallions, 4.7 feed units for 18 -month-olds and 7.8 feed units for 30-month-old stallions.
Stallions of different ages showed different growth rates during the fattening period (Table 6).

For 60 days of fattening, the live weight gain per head, on average, in 12 monthly stallions was $45.8 \mathrm{~kg}$ or $19.7 \%$ to the preliminary weight, in 24 monthly foals $-41.6 \mathrm{~kg}$ or $15.2 \%$ and in 6 monthly ones $-47.3 \mathrm{~kg}$. or 26.1 ; in 18 month-old stallions - $40.7 \mathrm{~kg}$. or 15.5 and in 30 -montholds -37.5 or $10.8 \%$ to the preliminary weight. The greatest average daily gains were in 6 monthly foals $788.3 \mathrm{~g}$, then in 12 monthly foals $-763.3 \mathrm{~g}$.

The results obtained will allow in the future to develop a comprehensive system for increasing the productivity and improving the breeding qualities of farm animals, on the example of AKBOZ LLP.

\section{Discussion}

The results of research have shown that the increase in the size index with age is due to a higher intensity of growth of the oblique length of the trunk, rather than the height at the withers. High growth of the chest girth index due to a higher energy of growth of the trunk in depth and width and the metacarpal bones in thickness, than the growth of the bones of the thoracic limb in length. A high massiveness index in foals is associated 
with a preemptive increase in body weight over the growth of foals in height and length.

Furthermore, we want to characterize other and the same horse breeds that were raised in other regions or under different breeding conditions for comparison with the horses studied in our work. Mongush and Yuldashbaev (2018) provided the results of the study of the external features of the stallions of the Tuvan local horse in the conditions of the tribal gene pool of the State Unitary Enterprise "Choduraa" of Tes-Khem district. Sturgeons and mares from the elite class were examined and evaluated on the basis of key indicators and indices, which characterize the type of body of the herd horse. These horses are also bred by the herd method. Successful stallions and mares were typical representatives of their elite class, which have the following average numbers (in $\mathrm{cm}$ ) of stallions: 142.7-147.0-173.0-19.0 live weight $437.5 \mathrm{~kg}$, mares: 138.6-144.0-165.5-17.8 live mass 390 $\mathrm{kg}$. In comparison with the Kazakh horses of the Jabe type, they surrender to all external characteristics.

Kargaeva et al. (2019) considered the study of meat productivity and morphobiochemical indicators of blood of Kazakh horses of the Jabe type in the conditions of the Mangistau region of the Republic of Kazakhstan.

The work established that the average daily growth was on average from birth to 2.5 years 368.3-372.0 $\mathrm{g}$ and during the period of bending two-year-olds- 701.7-708.9 $\mathrm{g}$ and the live weight at birth is $37.4 \pm 1.5 \mathrm{~kg}$.

At the same time, horses in the Almaty region outnumber competitors from the Mangistau region. This is primarily due to its geophysical features, as the Almaty region is rich in natural greenery and many mountains and the average devastation of sediments in the year is more than a mountain and the live weight at birth is $48.7 \pm 1.87 \mathrm{~kg}$.

It has been established that the largest plant of the living mass in the lottery in 2018. observed from $3-x$ daily age to 1 month was $40.8 \mathrm{~kg}$ in stallions and 40.4 $\mathrm{kg}$ in mares. The average daily growth rate was 1511 and 1496 respectively. From 1 month to 6 months of age, the growth of live mass is $84.8 \mathrm{~kg}$ in stallions, $83.0 \mathrm{~kg}$ in foals, the average daily growth was 543 and $532 \mathrm{~g}$, respectively.

Omarov (2013) reported the quantitative and qualitative composition of stallions and kobyl Seletinsky plant type different lines of the horse plant. The height of the stallion producers is $145.1 \pm 0.2 \mathrm{~cm}$, the length of the torso is $151.7 \pm 0.3 \mathrm{~cm}$, the circumference of the breast is $184.9 \pm 0.4 \mathrm{~cm}$, the circumference of the pelvis is $19.7 \pm 0.1 \mathrm{~cm}$, live weight was $471.0 \pm 1.7 \mathrm{~kg}$.

In the Pavlodar area the main improvement of local horses of productive direction is the Seletin factory type of Kazakh horses, created in 2010. On the horse factory "Altai Karpyk Saidaly Sarytoka" of the Irtysh area. In connection with this, in increasing the production of horse breeding in the Pavlodar region used more productive factory lines Braslet, Zadornogo and Pamir, well adapted to the conditions of the annual pastoraltebenevochno. It should be noted that the Seletin plant type of Kazakh horses, bred in the harsh conditions of the Pavlodar region, differs from the local Kazakh horses by a much higher live mass, large herds of sheep and goats, good grazing.

And our stallion producers have a height of $145.2 \pm 0.49 \mathrm{~cm}$ in the neck, a longitudinal length of the torso $151.05 \pm 0.64 \mathrm{~cm}$, a girth of the breast $184.3 \pm 0.75$ $\mathrm{cm}$, a girth of the pelvis $19.5 \pm 0.19$. $\mathrm{cm}$, living mass was $461.4 \pm 2.6 \mathrm{~kg}$. The results are not particularly different. Because the nature of the Almaty and Pavlodar regions is not particularly different. Both areas are rich in their own green grasses.

Growth and development indices of the Kazakh horses of Jabe type are expressed in intensive growth with favorable seasons of the year and slowdown in growth during the unfavorable seasons. At the same time, the difference in growth and development between stallions and fillies is insignificant.

Young stock of Kazakh horses of different ages during the period of feeding and intensive fattening is well added in live weight. With spring feeding, 12 months old foals gain $40.6 \mathrm{~kg}$ in live weight, 24 months old ones $-35.2 \mathrm{~kg}$. During the autumn feeding period, 6 months old foals increase their live weight on $46.3 \mathrm{~kg}, 18$ months old foals- on $37.2 \mathrm{~kg}$ and 30 monthly $-35.1 \mathrm{~kg}$.

During the fattening, the increase in live weight was $47.3 \mathrm{~kg}$ in 6-month-old stallions, $45.8 \mathrm{~kg}$ in 12 -monthold stallions, $40.7 \mathrm{~kg}$ in 18 -month-olds, $41.6 \mathrm{~kg}$ in $24-$ month-olds and $5 \mathrm{~kg}$ in 30 month-olds.

Similar results were obtained in the article «On meat productivity of young kazakh horses of the jabe type on the mangyshlak peninsula».

\section{Conclusion}

With year-round maintenance of horses on the pasture in the conditions of the genetic potential of animals by live weight was $66.7 \mathrm{~kg}$ in stallions and 48.8 $\mathrm{kg}$ in mares higher than in commercial farms. When studying the growth and development of foals, it was found that the highest average daily growth of 1511 and $1496 \mathrm{~g}$ is observed from 3 years of age to 1 month of age. When studying changes in exterior features during the development of foals from 3 to 6 months of age, it was found that a higher growth energy of foals was observed in the axial and weaker in the peripheral parts of the body. With the General development of foals, the most intensive growth is the oblique length of the trunk rather than the height at the withers. There is also a high massiveness index due to the high increase in body weight than the height at the withers. 
The Kazakh horse zhabe is a specialized breed of herd horses, capable of intensively increasing live weight during the feeding period and producing high quality meat, regardless of its belonging to the population or offspring.

\section{Acknowledgment}

We express our gratitude to the Kazakh National Research University and the staff of Akboz.

\section{Author's Contributions}

Shynggys Assilbekov: Participated in all experiments, coordinated the data-analysis and contributed to the writing of the manuscript

Kairat Iskhan: Designed the research plan and organized the study.

Nursultan Japashov: Coordinated the data-analysis and contributed to the writing of the manuscript.

Aidana Orynbassarova: Coordinated the mouse work and contributed to the wiring of the manuscript.

\section{Ethics}

The authors declare that the work is written with due consideration of ethical standards.

\section{References}

Akimbekov, A. R. (2013). Productivity Kazakh horses such as the toad at a dilution on lines. Publishing 1st international Scien tific Cobferebce/Appliedn Sciences in Europe: tendencies of contemporary development, Hosted by the ORT Publishing and The Center For Social and Political Studies" Premier". Stuttgart, Germany, 125-127.

Akimbekov, A., Baimukanov, D., Yuldashbaev, Y., Demin, V., \& Iskhan, K. (2018). Konevodstvo. Uchebnoe posobie (in Russian: КОНЕВОДСТВО Учебное пособие).

Akimbekov, A. R., \& Yuldashbaev, Y. A. (2017). Produktivnost' kazakhskikh loshadey tipa zhabe pri razvedenii po liniyam. Zootekhniya. (in Russian: Продуктивность казахских лошадей типа жабе при разведении по линиям. Зоотехния), (5), 11-13.

Baimukanov, D., Akimbekov, A., Yuldashbaev, Y., \& Iskhan, K. (2017). TEKHNOLOGIYA PROIZVODSTVA NATSIONAL'NYKH IZDELIY I BLYUD IZ KONINY V KAZAKHSTANE. Pishchevaya industriya. (in Russian: Технология производства национальных изделий и блюд из конины в Казахстане. Пищевая индустрия).
Egorova, I.K. (2017) Razvitiye innovatsionnykh protsessov v tabunnom konevodstve (na materialakh Respubliki Sakha (Yakutiya)) (Doctoral dissertation, Federal'noye gosudarstvennoye byudzhetnoye uchrezhdeniye nauki Sibirskogo federal'nogo nauchnogo tsentra agrobiotekhnologiy Rossiyskoy akademii nauk), (in Russian: Развитие инновационных процессов в табунном коневодстве (на материалах Республики Саха (Якутия)) (Doctoral dissertation, Федеральное государственное бюджетное учреждение науки Сибирского федерального научного центра агробиотехнологий Российской академии наук).

Kargaeva, M.T., Baimukanov, D.A., Dzhunisov, A.M., Alikhanov, O., Mongush, S.D., \& Mongush, S.D. (2019). ZAKONOMERNOSTI FORMIROVANIYA MYASNOY PRODUKTIVNOSTI TABUNNYKH LOSHADEY. Vestnik Tuvinskogo gosudarstvennogo universiteta. Yestestvennyye i sel'skokhozyaystvennyye nauki, (in Russian: ЗАКОНОМЕРНОСТИ ФОРМИРОВАНИЯ МЯСНОЙ ПРОДУКТИВНОСТИ ТАБУННЫХ ЛОШАДЕЙ. Вестник Тувинского государственного университета. Естественные и сельскохозяйственные науки) (4 (53)).

Kargayeva, M. T., Baimukanov, D. A., Karynbayev, A. K., Alikhanov, O., \& Zhunusov, A. M. (2020). Productive-biological features of aday breed kazakh horses. EurAsian Journal of BioSciences, 14(1), 329-335.

Mongush, B.M., \& Yuldashbaev, Yu.A. (2018). Ekster'yernyye osobennosti tuvinskikh zherebtsov i kobyl. Vestnik Tuvinskogo gosudarstvennogo universiteta. Yestestvennyye i sel'skokhozyaystvennyye nauki, (in Russian: Экстерьерные особенности тувинских жеребцов и кобыл. Вестник Тувинского государственного университета. Естественные сельскохозяйственные науки) (2).

Ombaev, A. M. (2013). Sovremennyye tendentsii razvitiya agrarnoy nauki Kazakhstana v oblasti zhivotnovodstva. Izvestiya Natsional'noy akademii nauk Respubliki Kazakhstan, (in Russian: Современные тенденции развития аграрной науки Казахстана в области животноводства. Известия Национальной академии наук Республики Казахстан), (6), 3.

Omarov, M.M. (2013). Razvedeniye seletinskogo zavodskogo tipa kazakhskikh loshadey zhabe. Izvestiya Orenburgskogo gosudarstvennogo agrarnogo universiteta, (in Russian: Разведение селетинского заводского типа казахских лошадей жабе. Известия Оренбургского государственного аграрного университета), (1 (39)). 
Shynggys Assilbekov et al. / American Journal of Animal and Veterinary Sciences 2021, 16 (1): 15.22 DOI: 10.3844/ajavsp.2021.15.22

Sataev, E., Iskhan, K., Baimukanov, D., \& Akimbekov, A. (2018). MOLOCHNAYA PRODUKTIVNOST' KUSHUMSKOY PORODY LOSHADEY Issledovaniya, rezul'taty. (in Russian: МОЛОЧНАЯ ПРОДУКТИВНОСТЬ КУШУМСКОЙ ПОРОДЫ ЛОШАДЕЙ. Исследования, результатьл.)
Zhumagaliyeva, G. M., Shynybayev, D. S., Dimov, D. P., Anarbekova, G. D., \& Akimzhan, N. (2015). Meat Qualities of Youngsters Received from Rams, Used in the Tupping of Dam at Early Age. Biosciences Biotechnology Research Asia, 12(1), 453-457. 